Journal

of Geography

Politics and Society

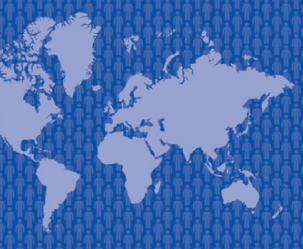

7(1)/2017

\section{Journal of Geography, Politics and Society}

$2017,7(1), 56-59$

DOI 10.4467/24512249JG.17.007.6206

\title{
STATE MECHANISMS OF ENSURING QUALITATIVE MODERNIZATION OF SECONDARY EDUCATION
}

\author{
Nadiya Karpeko \\ Educational, Scientific and Production Center, National University of Civil Protection of Ukraine, Lermontovska 28, 61024 Kharkiv, Ukraine \\ e-mail: nadezhda_v@list.ru
}

\section{Citation}

Karpenko N., 2017, State mechanisms of ensuring qualitative modernization of secondary education, Journal of Geography, Politics and Society, 7(1), 56-59.

\begin{abstract}
The article analyzes theoretical position of one of the problems of educational reform that allowed identify the ways to improve the branch system of economic relations in education and to define concrete steps on implementation assigned in connection with this task. Reforming education in Ukraine is part of the renewal of education systems associated with the recognition of the importance of knowledge as an engine of social welfare and progress. It is therefore particularly urgent study of all components of the system of secondary education: planning, assessment, prediction - at both national and regional levels.
\end{abstract}

\section{Key words}

economic mechanism, state regulation, reforming of education in Ukraine.

\section{Introduction}

Many scientists and politicians paid attention to the sphere of education today. Only countries which have a highly and corresponding to modern requirements of the education system, can to become one of developed nations of the modern world. Almost all countries show strong economic growth, a priority is the development of education.

In order to correctly perceive, analyze and evaluate information, a person must have sufficient intelligence and the necessary range of knowledge. The basis for this laid exactly at the level of secondary education, which makes increasingly high demands on the higher educational establishments.
Research organizational and economic mechanism in the common secondary education takes on special actuality today, when the discussion about reform (or modernization) in education system is not finished. It's carried among executives (not just the education system) and in academic circles. However, many liberal reformers proposals require careful critical analysis.

\section{Paper main body}

The main differences affecting such areas as reforming the economic mechanism of secondary 
education as a change in the status of educational institutions, the transition to the required funding and competitive procedure for placing the state order for specialists training. After acceptance into 1991 of the Law of Ukraine "On Education" (current version - of February 19, 2016) (Закон України..., 2016) was an important milestone in the development of new sectoral economic mechanism. The Law removed many inconsistencies in the model of the economic system that offered previously, elaborated and brought it closer to the existing realities of a number of key points, gave legal force to new economic solution.

However, experience shows that it is fixed economic model to date has largely obsolete. Today it's clear, that it is not an adequate system of modern economic relations in the area, and by that deforms it (Садковой, 2013).

Building concept of the new system of economic relations in education today involves several fundamental decisions and far from trivial issues.

The first step is to determine which balance the interests of participants of the educational process will show this system.

It is known, for example, industrial model, which operated under the planned economy distribution primarily takes into account the interests of the management structures of higher levels of vertical. In this case obviously it was assumed that top managerial authority not only understand, but also better than other express Interest all participants in the educational process. As a result, educational institutions essentially boiled down to the application level to the management system and completely lost their economic rights (Смолин, 2002).

Improving economic system of education, in our view, must use strategy of gradual modernization modern model of distribution of financial resources in the area and consistently grow there elements that provide educational services free choice of its customers.

Now the movement in this direction in the first place can be achieved by expanding the volume of paid educational services and is in ever-increasing extent be marked in the allocation of financial resources in the industry. In the same direction can be conducted and experimental work on local (with some areas) the introduction of special credit certificates (vouchers) to pay for major (performed as part of the mandatory program) educational services provided by institutions of general education ( $\mathrm{Cn}$ ницина, 2004).

As a whole, the proposed evolutionary path of development and distribution relationships in education is still the most appropriate because in the end the difficult socio-economic situation is not advisable to radically change the existing order of things and introduce innovations that are not tested during serious experimental work.

Anyway, in the short term seems best to build a new system of economic relations in education using the principle of individual expression of interest, mainly due to the so-called social order formed by the state, by the scheme: personal through the public, not vice versa (Байкова, 2007).

Modernizing the state economic mechanism in education must play better in the updated model of the specific educational institutions such as nonprofit organizations which profit is not the purpose of their operation. Unlike business corporations (enterprises, cooperatives etc.), educational institutions for their economic activity is not the main. It's just providing a process, so it should be considered (Myхін, 2008).

As a result of economic activity, for example, impossible to judge effectiveness of the educational institutions, including and economic efficiency. In education do not work and it is effective in other areas of economic mechanisms stimulating the growth of quality of manufactured products or services. Thus, under the effective influence of several objective reasons, educational institutions cannot significantly expand the volume of produced services, and this can interrupt natural for most sectors of the economy chain, improving product quality - increased demand for it - the increase in output growth - revenue producer. It means, we must find other incentives and other mechanisms improve the quality of manufactured products - education services. The study of the question shows that these mechanisms are in administrative regulation of the industry and within these reasons, in principle, inappropriate to model economic relations in education based on the canons adopted in a commercial environment (Смолин, 2002).

Moreover, in the world is considered normal when the current regulations, in a sense, hinder educational institutions interested in maximizing profits. And it is experienced by many established that in the pursuit of profit, these institutions will inevitably have to sacrifice quality services produced by them, and it certainly is contrary to their functional purpose (Головко et al., 2009).

Improving sectoral pattern of economic relations, it is necessary, as we have noted, consider that education is very different from other sectors of the economy manifest themselves market mechanisms of self-regulation system. Not all of them are "triggered" in this very specific area. For example, education in this area is very 
limited optimization capabilities of competition in the education market. And if in the field of vocational education and preschool education they can still give positive results, in general education are essentially powerless (Чикало, 2003).

It is obvious that in the countryside, competition between educational institutions virtually absent. Consumers are enjoying the services of those agencies that are directly in its settlements or at most a short distance from it. In such a situation, even if a number of wealthy parents of children using the material possibilities of the latter, and attend better, from their perspective, a school in another village or in the nearest town, the general economic condition of local schools is noticeably not affect. Budget allocations it receives almost the same volumes and reducing funding certainly not go beyond the significant annual fluctuations (Шукевич, 2015).

At the same time, such a mass character "migration" cannot receive, because firstly, not all consumers of educational services so desire, and secondly, not all willing enough this means.

Another situation, but the same results, in the modern city. Here, especially in large cities, students and their parents really great selection of secondary schools. However, in practice it is much narrower „production” capabilities of institutions that really work well and whose services are in demand. Limited resources, primarily personnel, potential does not allow them to accept all interested and does not allow to expand the volume of its activities. As a result, much of consumers of educational services have to get them to "ordinary" secondary schools and this provides them calm existence (Чижевський, 2005).

We know that competition in the market of goods and services allows to optimize territorial distribution of production. Its beneficial effect affects the development of all sectors of the economy and general education is only in this sense absolute exception. Here no competition producers or any other innovative market mechanisms do not have a direct effect on the placement of network of secondary schools (Шульгіна, Яковлев, 2004).

Thus, the study of the specific sector shows that market mechanisms in education system of self-regulation often do not work and so they should be duplicated mechanisms of administrative regulation. For example, competition between educational institutions does not create incentives to improve the quality of work, does not provide optimization of industry structure, not reduces the cost of education. All this shows that we should not invent new here, but questionable relative of economic necessity and effectiveness, building aimed at „inclusion” exactly economic mechanisms of the system (Огаренко, 2005).

If necessary a differentiated approach to the remuneration of teachers and financial ensuring the institutions have different quality parameters activities carried out by them, is enough to determine the category in the first case workers, and in the second case, institutions, based on these identified differences in their work. Moreover, determine these differences and identify criteria for assessing the quality of teaching, or more - educational activities should science. Economists remain here only justify differences in payments and provision. But these issues are not the subject of this study (Бесчастний, 2009).

Forming a new branch model of economic relations in education, need to know that educational institutions are not organizations that are financed just because they operate. Unlike management structures, educational institutions produce, albeit very specific, but nevertheless a quite definite marketable product - educational services. Therefore wrongly speak about financing of activity of these establishments because the customer pays not it, but obtained his services. This raises a whole complex of questions related to the organization pay for educational services that are performed under the state order (Калініна et al., 2002).

The fact that the segmentation of the educational market, where prices of the individual sectors are installed under a the influence of various factors, and usually at a very unequal level differentiation activities of educational institutions to "favorable" and „unfavorable” (Садковой, 2013). And since, for objective reasons, most low-paid types of work are those that are performed within the state order, that is the main educational activities of public institutions, eventually, through their efforts and redistribution of teaching staff in favor of a commercial plan - additional paid educational services.

\section{Conclusions}

Formation of a new economic model in education is a very complex and dynamic conditions of a fundamental restructuring of the entire system of economic relations in the country. Naturally, the specificity of this historical period has a high level of entropy in socio-economic development of society, and lays on it a special mark. In particular, it's relative high degree of openness created by the system to account for new phenomena in the economy and the social sphere, its inherent ability to transform in an environment that changes the content model 
and transition elements, designed for use in extraordinary circumstances of economic crisis.

With the stable economic development in education should be excluded following types of institutions to attract extra-budgetary funds as providing brokerage services to commercial organizations. It should greatly limit and lease of housings of educational institutions. It is well known that, as a rule, it is not caused by an excess in schools, orphanages, kindergartens and sports education institutions teaching space, and an acute shortage of these facilities for educational work.

\section{References}

Байкова О.М., 2007, Концептуальные основы государственной политики в области образования и экономические границы его коммерциализации, Экономика образования, 1, 98-110.

Бесчастний В.М., 2009, Розвиток інформаційного суспільства як позитивний чинник впливу на якість управління вітчизняною освітою, Державне управління: удосконалення та розвиток, 3, http://www.dy.nayka.com. ua/?op $=1 \& z=34[10.09 .2016]$

Головко Б.А. et al., 2004, Реформування вищої освіти у прочесі демократизачії українського суспільства, національний університетт ім. Т. Шевченка, ВПЦ “Київський університет", Київ.

Закон України «Про освіту» № 1060-XII, 23.05.1991, Редакція станом на 19.02.2016, Верховна Рада УРСР, http://zakon4.rada.gov.ua/laws/show/1060-12 [14.09.2016]

Калініна Л.М. et al., 2002, Теоретико-прикладні аспекти управління закладами освіти, Інститут педагогіки академії педагогічних наук України, Асоціація керівників школи України, Актуальна освіта, Київ.

Мухін М.І., 2008, Шляхи підвищення якості управління інновачійною діяльністю в освітній установі, Педагогічна академія післядипломної освіти, Київ.

Огаренко В.М., 2005, Методика застосування системи підтримки прийняття рішень по управлінню структурою пропозиції освітніх послуг, [in:] Актуальні проблеми державного управління. Випуск 2, Видавництво ХарРІ НАДУ “Магістр", Харків, 111-119.

Садковой В.П., 2013, Основні економічні механізми державного регулювання входження в європейський простір сучасної вищої освіти України, Державне будівничтво, 1, http://www.kbuapa.kharkov.ua/e-book/ db/2013-1/doc/2/10.pdf. [10.09.2016]

Синицина Н., 2004, Досягнення якісно нового рівня підготовки фахівців з державного управління засобами стандартизації галузевої вищої освіти, Управління сучасгим містом, 3(7), 274-279.

Смолин О.Н., 2002, Про регулювання економічних механізмів у сфері утворення, Економіка освіти, 2, 17-20.
Чижевський Б., 2005, Освітня політика в Україні : пріоритети, завдання, принципи та шляхи їх упровадження, Освіта України, 64, 6.

Чикало В.Г., 2003, Аналітична діяльність суб'єкта управління навчальним процесом Управління освітою в регіоні: пошуки оптимальних шляхів, [in:] Матеріали науково-пракичної конферениії, Сумський державний педагогічний університет імені А.С. Макаренка, Суми, 75-78.

Шукевич Б, 2015. Шляхи поповнення терміносистеми з дистанційного навчання, [in:] Українська термінологія і сучасність: Збірник наукових пращь. Випуск VI, KHEУ, Київ, 437-440.

Шульгіна В.Д., Яковлев О.В., 2004, Розвиток національної освіти в Україні в умовах відкритого інформаційного простору, [in:] Професіоналізм педагога: матеріали Всеукаїнської науково-практичної конференції, присвяченої 60-річчю Кримського деравного гуманітарного університетуту. Випуск 1, РВВ КДГІ, Ялта, 78-82. 